\title{
ESTIMATES COVARIANCE FUNCTIONS TO GOATS MILK PRODUCTION USING REGRESSION MODELS RANDOM
}

FONSECA,Wéverton José Lima ${ }^{1}$ FONSECA, Wéverson Lima BORGES, Laylson da Silva EVANGELISTA, Amauri Felipe SOUSA, Paulo Henrique Amaral Araújo de NASCIMENTO, Genilson Sousa do FIQUEIREDO, Carlandia Pacheco de ALMEIDA JÚNIOR, Teobaldo Florêncio de GUERRAS, Leandro de Oliveira

CAVALCANTE, Diego Helcias SOUSA JÚNIOR, Severino Cavalcante de

SUMMARY: The aim of this review was to estimate covariance functions for the production of Alpine breeds of goat milk and Saanen using random regression models. Conventional analysis for estimating components of (co) variance and genetic parameters for growth traits are performed by finite-dimensional models, which allows the construction and use of selection indexes and mixed model equations, obtaining parameters as heritability and genetic correlation. The random regression models (MRA) enable work with characteristics of genetic lactation curves for each animal or growth that are measured repeatedly in the animal's life, called longitudinal data.

Keywords: Genetic correlation. Dairy goats. Longitudinal data.

\section{ESTIMATIVAS DE FUNÇÕES DE COVARIÂNCIA PARA PRODUÇÃO DE LEITE DE CAPRINOS UTILIZANDO MODELOS DE REGRESSÃO ALEATÓRIA}

RESUMO: O objetivo com essa revisão foi estimar funções de covariância para produção de leite de caprinos das raças Alpina e Saanen utilizando modelos de regressão aleatória. As análises convencionais para estimar componentes de (co) variância e parâmetros genéticos, para características de crescimento são realizadas por modelos de dimensão finita, que permite a construção e emprego de índices de seleção e equações de modelos mistos, a obtenção de parâmetros como herdabilidade e correlação genética. Os modelos de regressão aleatória (MRA) possibilitam trabalhar com características de curvas de lactação genética para cada animal ou crescimento que são medidas repetidamente na vida do animal, denominados dados longitudinais.

Palavras-chave: Correlação genética. Caprinos leiteiros. Dados longitudinais.

\section{INTRODUCTION}

In Brazil the development of goat raising in recent years has required greater monitoring by the technicians responsible for the improvement of livestock. That way, has

\footnotetext{
${ }^{1}$ Mestrando em Ciência Animal, Centro de Ciências Agrárias, Universidade Federal do Piauí-CCA/UFPI), Teresina, Piauí, Brasil.
} 
emerged as the agricultural sector of great economic importance as a source of income for milk production and cut.

Goats are animals well adapted to the climate and situation of this country, being hardy animals, requiring very environmental and climatic conditions, which facilitates its inception, and even being adapted to the climate, the goats go through situations where the weather It is not favorable in warmer seasons in the various places where they are raised (VIANA et al., 2013).

Conventional analysis for estimating components of (co) variance and genetic parameters for growth traits are performed by finite-dimensional models, which allows the construction and use of selection indexes and mixed model equations, obtaining parameters as heritability and genetic correlation. The use of covariance functions is advantageous because it creates a more accurate covariance structure of features in research, allowing the prediction covariance structures for any point along a continuous range and allows the use measurements taken at any point of the trajectory (ASSIS et al., 2006).

The use of methods to estimate genetic parameters and predict breeding values more accurately, may contribute to the increase in earnings from the selection. The (MRA), called infinite dimensional models, enables work with characteristics of genetic lactation curves for each animal or growth that are measured repeatedly in the life of an individual, called repeated characteristics or longitudinal data.

The random regression models (MRA) has become an alternative to standard genetic analyzes of longitudinal data, a random barriers of the regression models is related to the requirement for memory and computation time to perform large scale genetic evaluations (SOUSA JÚNIOR et al., 2014).

Thus, the aim of this review to present the increase of studies covariance components for production of goat milk from Alpine and Saanen using random regression models.

\section{GOAT CULTURE}

In Brazil, the goat herd has been reaching increasingly higher socio-economic importance, particularly in the Southeast region of the country, which from the 70's that came the great interest in the commercial exploitation of suitable goat milk production. Given this interest, in 1974 was founded the Brazilian Association of Goat Breeders (ABCC), later giving rise to the Brazilian Association of Dairy Goat Breeders (CAPRILEITE) and in 1993, the Association of Sheep and Goat Breeders of Minas Gerais - ACCOMIG - CAPRILEITE (FONSECA e BRUSCHI, 2009). 
According to the IBGE (2013), Brazilian Institute of Geography and Statistics, the latest data from the Municipal Livestock Production in 2012, the national goat herd from the point of view of milk production, are identified two production centers, one in the northeast and one in the Southeast. About $75 \%$ of goat milk production in Brazil comes from the Northeast, mainly in the states of Rio Grande do Norte and Paraiba, while the Southeast region has $17 \%$ of the milk production of goats, concentrated in the states of Minas Gerais and Rio January (FONSECA; BRUSCHI, 2009).

In this sense, a viable alternative to better milk production in Brazil, is the introduction of goats of Saanen and Alpine by exceptional technical and economic results, as well as excellent adaptability to the tropical climate. The Saanen breed are more adapted to confinement animal due to fair skin. It originated in Switzerland in Berne Canton, in Saanen Valley with wider distribution around the world regarding other goat breed. In Brazil, the average daily milk production has varied from $2.5 \mathrm{~kg}$ to $4.9 \mathrm{~kg}$ for a lactation lasting 260-305 days (PEREIRA et al., 2011).

The Alpine breed originated in the Alps and are docile animals of medium and large and well adapted to Brazil and now represent the largest number of dairy herds in the country. Their average production of $2.5 \mathrm{~kg} /$ day of milk in a hot environment, characterized By effective temperature and high simulated solar radiation, heat-stress, decreased food intake, increased water consumption, they lost weight showed significant decline in milk production and its components (BRASIL et al., 2000).

\section{CURVES LACTATION}

Despite the goat milk is increasing production in Brazil, it is of great importance that increase. In the dairy goat, economic milk production is the most relevant feature (GUIMARÃES et al., 2006).

Knowledge of the magnitude of the lactation curve plays an important role in breeding goats, besides offering support for the planning of activity for many years, milk production test day (TDY's) were used only for calculating production cumulative total of each goat and that was used as the main criterion for selection of animals (BRITO, 2012). It is not necessarily accompanied by the improvement in the productivity of animals, aiming to improve that productivity is through the study of their lactation curves (MELO et al., 2011).

A lactation curve can be defined as the graphical representation of milk production throughout the lactation period and can assist in making decisions about changes in feeding management, disposal of animals or even in selection programs (BRITO, 2012). Its importance lies in the broad 
characterization of animal production throughout lactation, and can be identified: time to rise to peak, peak production, fall time (persistence of production or lactation), lactation length, length of service period, length of gestation, and sudden drops in production, response to diets, management, etc. (CHAVES, 2009).

In many research on the production of milk, they used statistical models to describe the lactation curves, with a practical and consistent way to obtain information on peak production and persistency of lactation (COBUCI et al., 2000; MC MANUS et al., 2003; MUNIZ et al., 2007; MENEZES et al., 2010).. As Guimarães et al. (2006), the most used model for estimating lactation curves is the incomplete gamma function proposed by Wood (1967), which has provided good fit lactation curves. Also, simple designs such as Wood (1967) have the advantage of providing a biological interpretation of their parameters.

According to Jacopini et al. (2011) The importance of lactation curve lies in the extensive characterization of livestock throughout lactation, and can be identified: the rise time to peak, peak yield, decay time (persistence production or lactation), duration of lactation, dry period length, duration of pregnancy, and sudden drops in production, response to diet and management, among other factors. As Mcmanus (2003), by the lactation curve it may be accompanied by the evolution of milk production of animals, knowing the variations along a lactation, by estimating production of partial or total.

\section{RANDOM REGRESSION MODELS}

In 1982, Henderson Jr. proposed an alternative for analyzing longitudinal data, which is the use of random regression models, bypassing the problem of super parameterization of multicaracterísticos models. The (MRA) can also be called infinite-dimensional models, since there are individual and infinite measured by such measures are more correlated, the closer together (EL FARO; ALBUQUERQUE, 2003). These are suitable for longitudinal data analysis, due to address the weaknesses of the conventional methods of quantitative genetic analyzes, which are considered phenotypic values intrinsically continuous processes (SOUSA JUNIOR, 2007).

For the study of longitudinal data, such as growth characteristic, the use of random regression models allows obtaining genetic parameters at any age within the range considered (SOUSA JÚNIOR et al., 2010). Another advantage of this model is to estimate more accurately the genetic and phenotypic covariance components, because they take into account the measurements as a function of time, using information from all observations and also allow to 
obtain estimates for the temporary environmental variance or error measurement (KIRKPATRICK et al., 1990).

The disadvantage of MRA, several authors cite the increase in computer application, due to the higher number of random effects by animal, in the equations of mixed models, and the fact that the analyzes considering the production test day have a greater number of observations that analyzes considering the production in 305 days (JAMROZIK e SHAEFFER 1997; SCHAEFFER et al., 2000).

However, with the advancement in the current hardware technologies affordable to breeding programs, the largest application becomes irrelevant. So it seems acceptable that emphasis should be given greater statistical and biological properties of the genetic evaluation methodologies compared to the computational cost of the same (PEREIRA, 2009).

The modeling of fixed regression curves and random additive genetic and permanent environment has been made through the use of functions such as orthogonal Legendre polynomials of various orders (BREDA et al., 2006; BIGNARDI et al., 2011; SILVA, 2011). The orthogonal Legendre polynomials are not parametric functions widely used to study the covariance structure for random additive genetic effects and permanent environment for longitudinal data.

As Silva (2011) analyzed 20710 PLDC records of 667 Alpine goats in order to identify the best random regression model using orthogonal Legendre polynomials. The MRA using orthogonal polynomial of Legendre most suitable for PLDC of the genetic evaluation of Alpine breed goats was what he considered the fixed curve of order four, the curve of genetic effects of additives order two, the curve of permanent environmental effects of order seven and at least five classes of residual variances (BRITO, 2012).

\section{LONGITUDINAL DATA ANALYSIS MODELS}

The characteristics are measured several times during the life of the animal are considered as longitudinal, or infinite dimensional characteristics. According to SARMENTO et al. (2006) The analysis of milk production data for the goat life can be conducted through the repeatability models, where milk production in different periods of lactation would be considered as the characteristic repeated, with the assumption of homogeneity of variance genetic and nongenetic throughout lactation, which is not true.

However, in this model, it is assumed that the correlation between repeated measurements is equal to unity, and all genetic and phenotypic covariance between the different measures are of the same magnitude, ie, the same genes control performance over time (ALBUQUERQUE, 
2004). In the situation where the repeated observations follow some kind of curve (eg, growth curves or lactation), the correlations among the closest observations in time are greater than those further away. In this case, a more complex model that considers different correlation structure between successive observations is necessary (SPEIDEL et al., 2010).

An alternative is to consider each measured as a different characteristic and perform a conjoint analysis on a model multicaracterísticas, which is a common approach analyzes for different characteristics of interest (MUCARI e OLIVEIRA, 2003; SARMENTO et al., 2003; SIQUEIRA et al., 2003; FARIA et al., 2007). Compared to the previous analysis, this has the advantage of offering different estimates of correlation between measurements, but without any covariance assuming structure, depending on the number of steps involved in analysis is necessary to estimate a large number of parameters, increasing the cost computer (NETO, 2012).

According to Menezes (2010), the longitudinal characteristics can be analyzed also by means of multicaracterísticos models, assuming that each weight set for standard ages is a different characteristic. Multicaracterísticas genetic evaluations predict breeding values for different ages through the incorporation of genetic and residual covariance between the ages (Spiedel et al. 2010). Another important point in this type of analysis is that the number of parameters to be estimated increases sharply with increasing numbers of features (MENESES, 2010).

\section{COVARIANCE FUNCTIONS}

The covariance functions (FC) can be defined as a continuous function providing the features of covariance measurements at different points of a trajectory (lactation), in describing the covariance between measurements taken at certain ages (days in milk) as a function of these ages (VAN DER WERF; SCHAEFFER, 1997). As Meyer e Hill (1997) demonstrated that the covariance function coefficients can be estimated from the ARM. Thus, different functions can be employed to adjust the trajectory over time. Among the parametric functions, highlight the exponential function Wilmink (Wilmink, 1987) and the logarithmic function of Ali e Schaeffer (ALI; SCHAEFFER, 1987).

As Kirkpatrick e Heckman (1989) show three advantages of the model covariance functions over traditional designs multi-characteristics. The first is that the covariance functions produce a description for any point along a continuous scale measures, allowing the covariance measured between ages not be easily obtained by interpolation. Another advantage is that each covariance function has a set of eigenvalues and eigenfunctions that provide information about 
the direction in which the mean curve (growth, lactation, etc.) are more likely to be modified by selection, since they have greater genetic variance.

The estimation of the covariance between the random regression coefficients produces estimates of covariance functions, which refer to a continuous structure description (co) variance for the character age range covered by the data, that is, a covariance function describes the covariance between measurements taken at certain ages as a function of these ages (KIRKPATRICK et al., 1990). Meyer (1998) demonstrated the equivalence between the random regression models and covariance functions. Thus, when setting a random regression model, it assumes a certain covariance structure between the random regression coefficients, which is imposed by the fitted function, and can be characterized by a continuous function and a covariance function (PESSÕA, 2011).

According to Meyer (1998), random regression models are a special case of covariance functions, and allow to estimate the coefficients of the covariance functions for using the restricted maximum likelihood (REML). In selection experiment for growth, random regression model used in the estimation of genetic parameters for days to calving in Nellore females, indicating that their application to the days of records for childbirth provided detailed analysis of the behavior of genetic covariance and genetic value the female reproductive performance over the course of his life, which may be appropriate in many studies (MERCADANTE et al., 2002).

\section{CONCLUSIONS}

Dairy goat has stood out in the Brazilian scenario, being a good source for products with a high high biological value and income for the population as one of the most important activities for the survival of producers in the Brazilian semiarid region.

The use of covariance functions is advantageous because it creates a more accurate structure of the covariance characteristics, which allows the prediction covariance structures for any point along a continuum allowing measurements taken at any point of the path.

The random regression models (MRA) have come up showing the standard procedure for genetic analysis of longitudinal data over the past decades, which allow thus to work with measures taken numerous times during the life of an individual, ie, repeated in time. 


\section{REFERENCES}

ALBUQUERQUE, L. G. Regressão aleatória: Nova tecnologia pode melhorar a qualidade das avaliações genéticas. In: V Simpósio Brasileiro de Melhoramento Animal, 2004, Pirassununga. Anais...Pirassununga, SBMA 2004.

ALI, T. E.; SCHAEFFER, R. Accounting for covariances among test day milk yields in dairy cows. Canadian Journal of Animal Science, v. 67, p. 637-644, 1987.

AN DER WERF, J.; SCHAEFFER, L. Random regression in animal breeding. Ontário: University of Guelf, 1997. 70p.

ASSIS, G. M. L.et al. Estimação de parâmetros genéticos em caprinos leiteiros por meio de análise de regressão aleatória utilizando-se a Amostragem de Gibbs. Revista Brasileira de Zootecnia, v. 35, p. 706-714, 2006.

BIGNARDI, A. B. Modelos para estimação de componentes de (co) variância para produção de leite no dia do controle de vacas da Raça Holandesa. 2010, 57p. Tese (Doutorado) Universidade Estadual Paulista, UNESP, Jaboticabal, 2010.

BIGNARDI, A. B.; El FARO, L.; TORRES JÚNIOR, R. A. A. Random regression models using different functions to model test-day milk yield of Brazilian Holstein cows. Genetic and Molecular Research, v. 10, n. 4, p. 3565-3575, 2011.

BRASIL, L. H. A.et al. Efeitos do Estresse Térmico Sobre a Produção, Composição Química do Leite e Respostas Termorreguladoras de Cabras da Raça Alpina. Revista Brasileira de Zootecnia, v. 29, p. 1632-1641, 2000.

BREDA, F. C.; ALBUQUERQUE, L. G.; YAMAKI, M. Estimação de parâmetros genéticos para produção de leite de cabras da raça Alpina. Revista Brasileira de Zootecnia, v. 35, p. 396-404, 2006.

BRITO, L. F. Modelagem da produção de leite de cabras das raças Alpina e Saanen utilizando regressão aleatória. 2012, 82p. Dissertação (Mestrado) - Universidade Federal de Viçosa, 2012.

CHAVES, L. C. S. Avaliação genética em bubalinos leiteiros utilizando modelos de regressão aleatória. 2009, 77p. Tese (Doutorado) - Universidade Federal de Viçosa, 2009.

COBUCI, J. A.et al. Curva de lactação na raça Guzerá. Revista Brasileira de Zootecnia, v. 29, p. 1332-1339, 2000.

EL FARO, L.; ALBUQUERQUE, L. G. Utilização de modelos de regressão aleatória para produção de leite no dia do controle, com diferentes estruturas de variância residuais. Revista Brasileira de Zootecnia, v. 32, p. 1104-1113, 2003.

FARIA, C. U.et al.Bayesian inference in a quantitative genetic study of growth traits in Nelore cattle (Bos indicus). Genetics and Molecular Biology, v. 30 p. 545-551, 2007. 
FONSECA, J. F.; BRUSCHI, J. H. A. Caprinocultura leiteira no Brasil: Uma visão histórica. In: Produção de caprinos na região da mata atlântica. Sobral, Embrapa Caprinos, Cap. 1, p. 1524, 2009.

GUIMARÃES, V.P.; RODRIGUES, M.T.; SARMENTO, J.L.R. Utilização de funções matemáticas no estudo da curva de lactação em caprinos. Revista Brasileira de Zootecnia, v. 35, p. 535-543, 2006.

IBGE, Instituto Brasileiro de Geografia e Estatística. Produção da Pecuária Municipal 2012, Rio de Janeiro, 2013.

JACOPINI L. A.et al. Leite e Cabra: Características e ualidades. Revista acta Tecnológica, v. 6, p. 1, 2011.

JAMROZIK, J.; SCHAEFFER, L. R. Estimates of genetic parameters for a test day model with random regressions for production of first lactation Holsteins. Journal Dairy Science, v. 80, p. 762-770, 1997.

KIRKPATRICK, M., LOFSVOLD, D., BULMER, M. Analysis of the inheritance, selection and evolution of growth trajectories. Genetics, v. 124, p. 979-93, 1990.

MCMANUS, C.et al. Fatores que influenciam os parâmetros das curvas de lactação em cabras no distrito federal. Revista Brasileira de Zootecnia, v. 32, p. 1614-1623, 2003.

MELO, A. L. P.et al. Identificação e modelagem da autocorrelação residual no ajuste do modelo de Wood às curvas de lactação de cabras. Ciência Rural, v. 41, p. 1818-1822, 2011.

MENEZES, G. R. O. Uso de polinômios segmentados na modelagem de dados longitudinais de ponderal em bovinos da raça Tabapuã. Tese (Doutorado) Universidade Federal de Viçosa, 2010 .

MENEZES, G. R. O.et al. Avaliação de medidas da persistência da lactação de cabras da raça Saanen sob modelo de regressão aleatória. Revista Brasileira de Zootecnia, v. 39, p. 1691-1698, 2010.

MERCADANTE, M. E. Z.et al. Dias ao Parto de Fêmeas Nelore de um Experimento de Seleção para Crescimento. II - Modelo de Regressão Aleatória. Revista Brasileira de Zootecnia, Viçosa, v. 31, p. 1726-1733, 2002.

MEYER, K. Estimating covariance functions for longitudinal data using a random regression model. Genetics Selection Evolution, Paris, v. 30, p. 221-49, 1998.

MEYER, K.; HILL, W. G. Estimation of genetic and phenotypic covariance functions for longitudinal or "repeated" records by restricted maximum likelihood. Livestock Production Science, v. 47, p. 185-200, 1997.

MUCARI, T. B.; OLIVEIRA, J. A. Análise genético-quantitativa de pesos aos 8, 12, 18 e 24 meses de idade em um rebanho Guzerá. Revista Brasileira de Zootecnia, v. 32, p. 1604-1616, 2003.

MUNIZ, J. A. Evaluation of lactation curve of lowyielding gir cows: a Bayesian approach. Acta Scientiarum Animal Science, v. 29, p. 79-83, 2007. 
PEREIRA, G. M.et al. Avaliação do comportamento fisiológico de caprinos da raça Saanen no semiárido Paraibano. Revista Verde, Mossoró, v. 6, n. 1, p. 83-88, janeiro/março. 2011. http://revista.gvaa.com.br.

PEREIRA, R. J. Medidas de persistência da produção de leite em rebanhos Gir Leiteiro usando modelos de regressão aleatória. 2009, 68p. Dissertação (Mestrado) - Universidade Federal de Viçosa, 2009.

PESSOA, M. C. Estudo do valor adaptativo anual de fêmeas da raça nelore utilizando modelos de regressão aleatória. Dissertação, Faculdade de Ciências Agrárias e Veterinárias UNESP, 2011.

SARMENTO, J. L. R.et al. Avaliação genética de caprinos da raça Alpina utilizando-se a produção de leite no dia do controle. Revista Brasileira de Zootecnia, v. 35, p. 443-451, 2006.

SARMENTO, J. L. R.et al.Efeitos ambientais e genéticos sobre o ganho em peso diário de bovinos Nelore no estado da Paraíba. Revista Brasileira de Zootecnia, v. 32, p. 325-330, 2003.

SCHAEFFER, L. R.; JAMROZIK, J.; KISTEMAKER, G. J. Experience with a est day model. Journal of Dairy Science, v. 83, p. 1135-1144, 2000.

SILVA, F. G. Estudo da produção de leite de caprinos utilizando modelos de regressão aleatória. 2011, 143p. Dissertação (Mestrado) - Universidade Federal de Viçosa, 2011.

SIQUEIRA, R. L. P. G.et al. Análise da variabilidade genética aditiva de características de crescimento na raça Nelore. Revista Brasileira de Zootecnia, v. 32, p. 99-105, 2003.

SOUSA JÚNIOR, S. C. Estimativas de funções de covariância para características de crescimento da raça Tabapuã utilizando modelo de regressão aleatória. 2007, 53p. Dissertação (Mestrado) - Universidade Federal do Ceará, 2007.

SOUSA JÚNIOR, S. C.et al. Aplicação de modelos de regressão aleatória utilizando diferentes estruturas de dados. Ciência Rural, v. 44, p. 2058-2063, 2014.

SOUSA JÚNIOR, S. C.et al.Estimação de funções de covariância para características de crescimento da raça Tabapuã utilizando modelos de regressão aleatória. Revista Brasileira de Zootecnia, v. 39, p. 1037-1045, 2010.

SPIEDEL, S. E.; ENNS, R. M.; CREWS JR.; D. H. Genetic analysis of longitudinal data in beef cattle: a review. Genetics and Molecular Research, v. 9, p. 19-33, 2010.

VIANA, M. P.; MEDEIROS, A. R.; SOUZA, B. B. Efeitos do estresse térmico sobre a fisiologia, produção e reprodução de caprinos. Agropecuária científica no semiárido, v. 9, p. 01-08, 2013.

WILMINK, J. B. M. Adjustment of test-day milk, fat and protein yields for age, season and stage of lactation. Livestock Production Science, v. 16, p. 335-348, 1987.

WOOD, P.D.P. Algebraic model of the lactation curve in cattle. Nature, v. 216, p. 164-165, 1967. 